\title{
Field Trip B (27 September 2018): Quaternary environments of Giessen and its surrounding areas
}

\author{
Johanna Lomax ${ }^{1}$, Raphael Steup ${ }^{1}$, Lyudmila Shumilovskikh ${ }^{2}$, Christian Hoselmann ${ }^{3}$, Daniela Sauer ${ }^{4}$, \\ Veit van Diedenhoven ${ }^{1}$, and Markus Fuchs ${ }^{1}$ \\ ${ }^{1}$ Department of Geography, Justus Liebig University Giessen, Senckenbergstr. 1, 35390 Giessen, Germany \\ ${ }^{2}$ Department of Palynology and Climate Dynamics, University of Göttingen, \\ Wilhelm-Weber-Str. 2a, 37073 Göttingen, Germany \\ ${ }^{3}$ Hessisches Landesamt für Naturschutz, Umwelt und Geologie, Rheingaustr. 186, 65203 Wiesbaden, Germany \\ ${ }^{4}$ Department of Physical Geography, University of Göttingen, Goldschmidtstr. 5, 37077 Göttingen, Germany
}

Correspondence: Johanna Lomax (johanna.lomax@geogr.uni-giessen.de)

Relevant dates: $\quad$ Published: 20 August 2018

How to cite: $\quad$ Lomax, J., Steup, R., Shumilovskikh, L., Hoselmann, C., Sauer, D., van Diedenhoven, V., and Fuchs, M.: Field Trip B (27 September 2018): Quaternary environments of Giessen and its surrounding areas, DEUQUA Spec. Pub., 1, 15-28, https://doi.org/10.5194/deuquasp-1-15-2018, 2018.

\section{Introduction}

Our 1-day field trip will first lead us to an area south of Marburg in the middle reach of the Lahn valley. After an introduction to the natural settings of the area, we will visit the gravel quarry of Niederweimar, one of the largest of its kind in Hesse. The gravel quarry exposes three units of gravel which possibly represent the remains of different Quaternary glacial periods. The gravels are covered by late glacial and Holocene floodplain fines, showing a high-resolution stratigraphy. The floodplain fines include tephra of the Laacher See eruption that took place during the Allerød, and alternating layers of sands and silts, which may reflect climatic fluctuations of the late glacial. Above the tephra, a dark soil horizon marks the beginning of Holocene conditions. Furthermore, the area around Niederweimar is rich in archaeological finds of different periods. They indicate continuous settlement in the area over the last 11000 years. Details will be presented at our coffee break at the so-called Zeiteninsel (island of times), an open-air museum showing settlements of different archaeological periods. Our next stop will be the abandoned gravel quarry Niederwalgern, which exposes gravels of the Lahn at the base and a thick sequence of floodplain fines, in- cluding a dark palaeosol. The sediments indicate massive deposition during the Holocene, probably due to anthropogenic forest clearing in the surrounding area. At our third stop, we will visit a loess palaeosol section south of Gießen, near a small village called Münzenberg. Our luminescence ages indicate that this profile comprises Middle Pleistocene loess, and possibly also a pre-Eemian palaeosol. The last glacial loess includes the Eltville tephra, another important tephra of the area, serving as a chronological marker for the Last Glacial Maximum. Establishing a secure chronostratigraphy at the site is however challenging, due to the position on a steep slope, which triggers erosional events.

\section{Physiogeographic setting of the area}

The geomorphological and geological setting of the area comprises a complex pattern of different geological units ranging from the Palaeozoic to the Holocene. An overview of the topography and geological units is shown in Figs. 1 and 2. The current annual rainfall in the area approximates $700 \mathrm{~mm}$, and the average annual temperature is $8.8^{\circ} \mathrm{C}$.

The main unit in the western part of the excursion route is represented by the Rhenish Massif (Rheinisches Schiefer- 


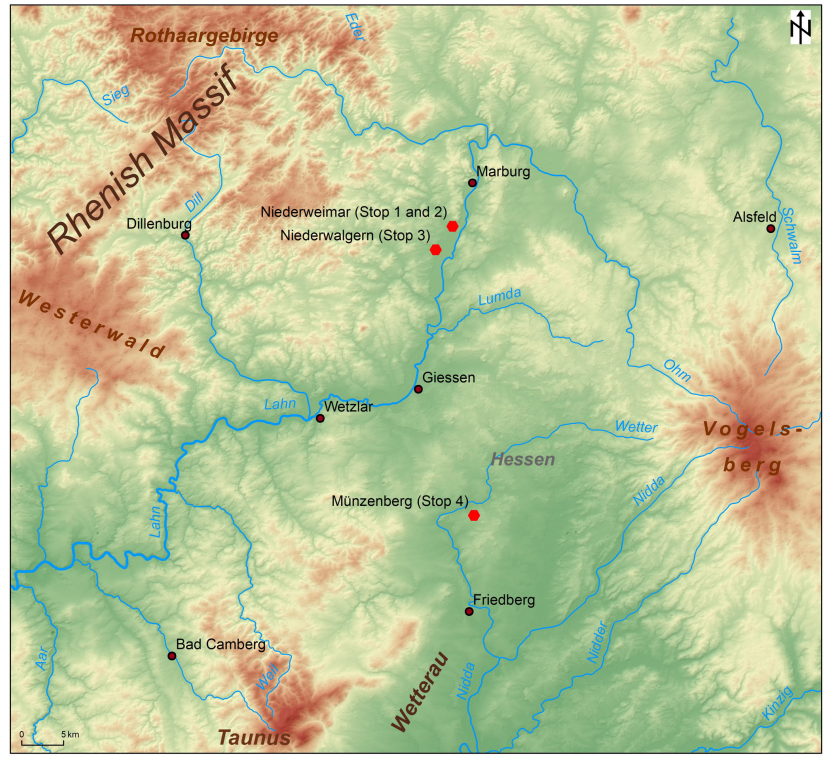

Figure 1. Topography of the field trip area and stops of the excursion route.

gebirge). Marine sands, silts and clays were deposited during the Devonian era, and were later metamorphized to quartzites and slates during the Variscian orogeny (Carboniferous). Locally, limestone, greywacke and radiolarite are also present, the last two especially in an area west of Gießen and Marburg. The Variscian orogen was eroded to its shield during the Permian era. During the Tertiary, the shield was fragmented into several fault blocks, of which some were uplifted during the Tertiary and the Quaternary. Examples of these uplifted blocks are, e.g. the Rhenish Massif or the Harz further to the northeast. Many of the gravels in the gravel quarry at Niederweimar (Stop 1) originate from the Rhenish Massif to the west, like quartzite, radiolarites and greywacke. Locally, this part of the Rhenish Massif is also called the Gladenbach Uplands (Gladenbacher Bergland). It has an average elevation of around $500 \mathrm{~m}$ a.s.l.

To the north and north-east of the excursion route, we mainly find red sandstones of the lower Triassic (Buntsandstein) and basalts which originate from the Vogelsberg eruption during the Tertiary (peak activity ca. $15 \mathrm{Ma}$ ago). The Vogelsberg is the largest contiguous volcanic region in central Europe. The highest elevation of the Vogelsberg area is the Taufstein (773 ma.s.l.). The river Lahn intersects the Buntsandstein in an area north and south of Marburg, forming a relatively steep valley. At Niederweimar (Stop 1), the valley opens into a wider basin, which is filled with Pleistocene gravels and Holocene floodplain fines of the river Lahn. Buntsandstein and basalts are further important components of the gravel spectrum in the gravel pit at Niederweimar.

Further geomorphological-tectonic units near Gießen and Marburg are depressions which are filled with Tertiary fines
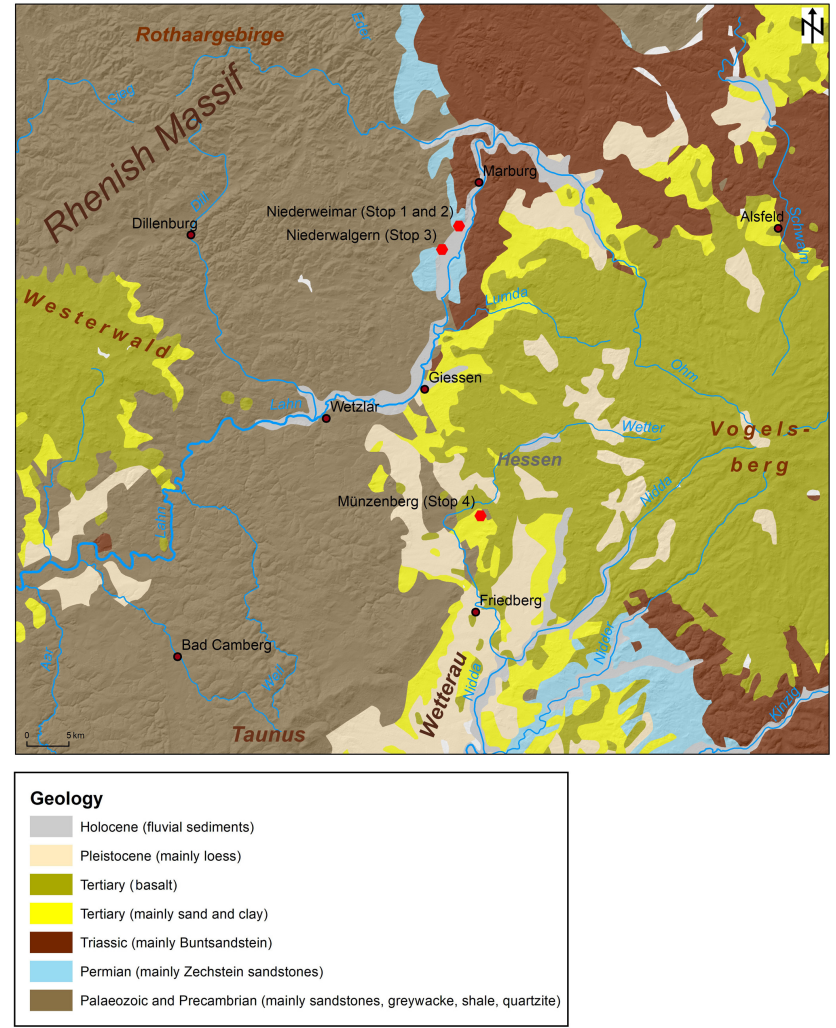

Figure 2. Simplified geology of the excursion area (database: Geological Map $1: 300000$ ).

and/or Pleistocene loess. The latter will be the focus of Stop 4. Like the uplifted Rhenish Massif, these basins represent tectonic blocks, which formed and subsided during the Tertiary and Quaternary.

\section{Gravel quarry at Niederweimar}

\subsection{Geology and geomorphology}

The gravel quarry at Niederweimar is situated south of Marburg in the central Lahn valley. It is one of the largest gravel quarries in Hesse. The middle reach of the Lahn cuts through a wide range of geological units such as the Rhenisch Massif and sandstones of Permian and lower Triassic age. Tributaries coming in from the east pass the basaltic Vogelsberg massif. This leads to a rather diverse gravel spectrum, dominated by greywacke, associated with radiolarites, sandstones, basalts and quartzites. The hard rock base of the gravel pit is formed by red to purple sandstones and claystones of upper Permian age (Zechstein). Sediments within the gravel pit have not only been deposited by the river Lahn, but also by the river Allna, a tributary flowing in from the west, sourced in the Rhenish Massif. More detailed information on the fluvial history of the Lahn valley near Marburg can be found in Heine (1970). 


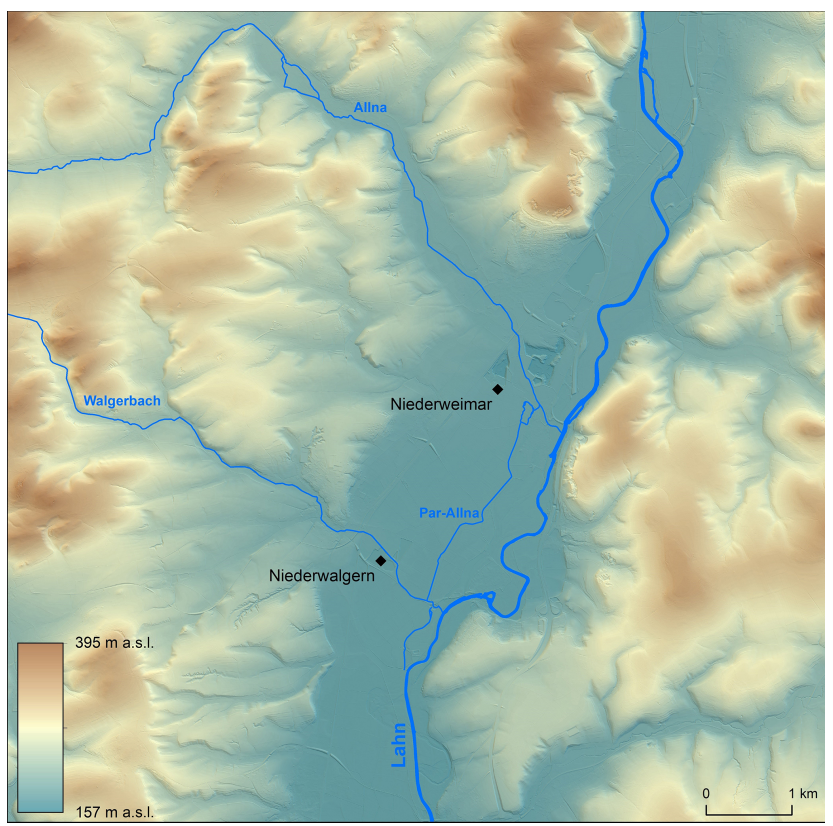

Figure 3. Digital elevation map of the area around the gravel quarries Niederweimar and Niederwalgern (Stop 1 and Stop 3).

From a geomorphological point of view, the gravel pit is situated on the lower terrace of the Lahn. It is currently not inundated by floods, and its cover sediments are of Late Pleistocene and early Holocene age, as evidenced by the Laacher See tephra (LST; 12900 ka, van den Boogard, 1995). Chronostratigraphically, the lower terrace would be assigned to the last glacial period. However, it appears that three gravel units are exposed in the pit, of which the lower ones seem to be much older than the last glacial. Elevation differences in the past and current floodplain of the Lahn are minimal (see Fig. 3); thus it is nearly impossible to distinguish different terrace levels from a geomorphological point of view. It therefore appears that at this location of the Lahn River, we are not dealing with a classical staircase of terraces, but with vertical stacking of terrace units, possibly due to (relative) tectonic subsidence in this part of the Lahn valley. So far, several radiocarbon ages, pollen and macrofossil assignments of the cover sediments as well as the gravel units have existed (e.g. Huckriede, 1982; Urz, 1995; Schirmer, 1999; Freund and Urz, 2000; Bos and Urz, 2003). But since large parts of the gravel units are older than $40 \mathrm{ka}$, numerical ages in particular of the older gravel units have been missing so far. New optically stimulated luminescence (OSL) and ${ }^{14} \mathrm{C}$ ages for the gravels as well as the floodplain loams are presented on this field trip.

\subsection{Archaeology}

During more than 20 years of excavation by the State Archaeological Service of Hesse on ca. 70 ha of river floodplains and adjacent alluvial terraces, a large area of settlements has been detected, spanning from the Mesolithic (11.7 to $7.5 \mathrm{ka}$ ) and different periods of the Neolithic (7.5 to $4.2 \mathrm{ka}$ ), Bronze (4.2 to $2.8 \mathrm{ka}$ ) and Iron Age (2.8 to $2.0 \mathrm{ka}$ ) to the Middle Ages. Such an extensive colonization of a local river landscape is, as yet, unique. The possibility to settle on the drier terraces near the water, as well as the species-rich flora and fauna, made the river landscape of the central Lahn valley attractive to humans (Bos and Urz, 2003).

Already in 1994, two early Mesolithic sites were found during a gravel excavation. They were dated to around $10.5 \mathrm{kacal} \mathrm{BP}$ (Bos and Urz, 2003). Pollen and macrofossil analyses, which were part of two research projects during the DFG (German Research Foundation) priority programme "Changes of the Geo-Biosphere during the last 15000 years, continental sediments as evidence for changing environmental conditions", suggest that forest-clearing due to deliberate burning by Mesolithic people occurred in the area (Bos and Urz, 2003). A reconstruction of the Mesolithic landscape in the central Lahn valley is shown in Fig. 4.

Since 2017, a DFG-funded research project has focused on plant remains from archaeological records as a source of information on the changing environmental conditions and agricultural systems within the prehistoric settlements near Niederweimar (Ralf Urz, Department of Geography, Philipps University of Marburg). Further details on the archaeology of Niederweimar can be found on the homepage of the archaeological survey of Hesse (https://lfd.hessen.de, last access: 11 July 2018).

\subsection{Gravel unit}

The gravel unit can be divided into three subunits (Fig. 5). The oldest unit (Unit I) forms the base of the gravel pit. It is not present and/or visible in all parts of the pit and is of dark grey to dark reddish colour. Unit II consists of brown gravels with trough and horizontal bedding and with a strong overprint caused by precipitation of iron oxides. This unit can be further divided into two subunits, separated by a discontinuous layer of larger blocks. Unit III is formed by greyish gravels with marked horizontal and trough bedding and a block layer at its base. Unit II and III are separated by an erosional disconformity. Further information on the gravel units is given in Freund and Urz (2000) and Urz (1995). They assign the lower part of the gravels (our Unit II) to the early Weichselian, based on pollen and macrorest analyses, and the upper part of the gravels (our Unit III) to the last Pleniglacial. The latter is supported by one ${ }^{14} \mathrm{C}$ age at Niederweimar of around $32 \mathrm{ka}$, and two further ${ }^{14} \mathrm{C}$ ages between 30 and $40 \mathrm{ka}$ at the gravel quarry Niederwalgern (Urz, 1995). 


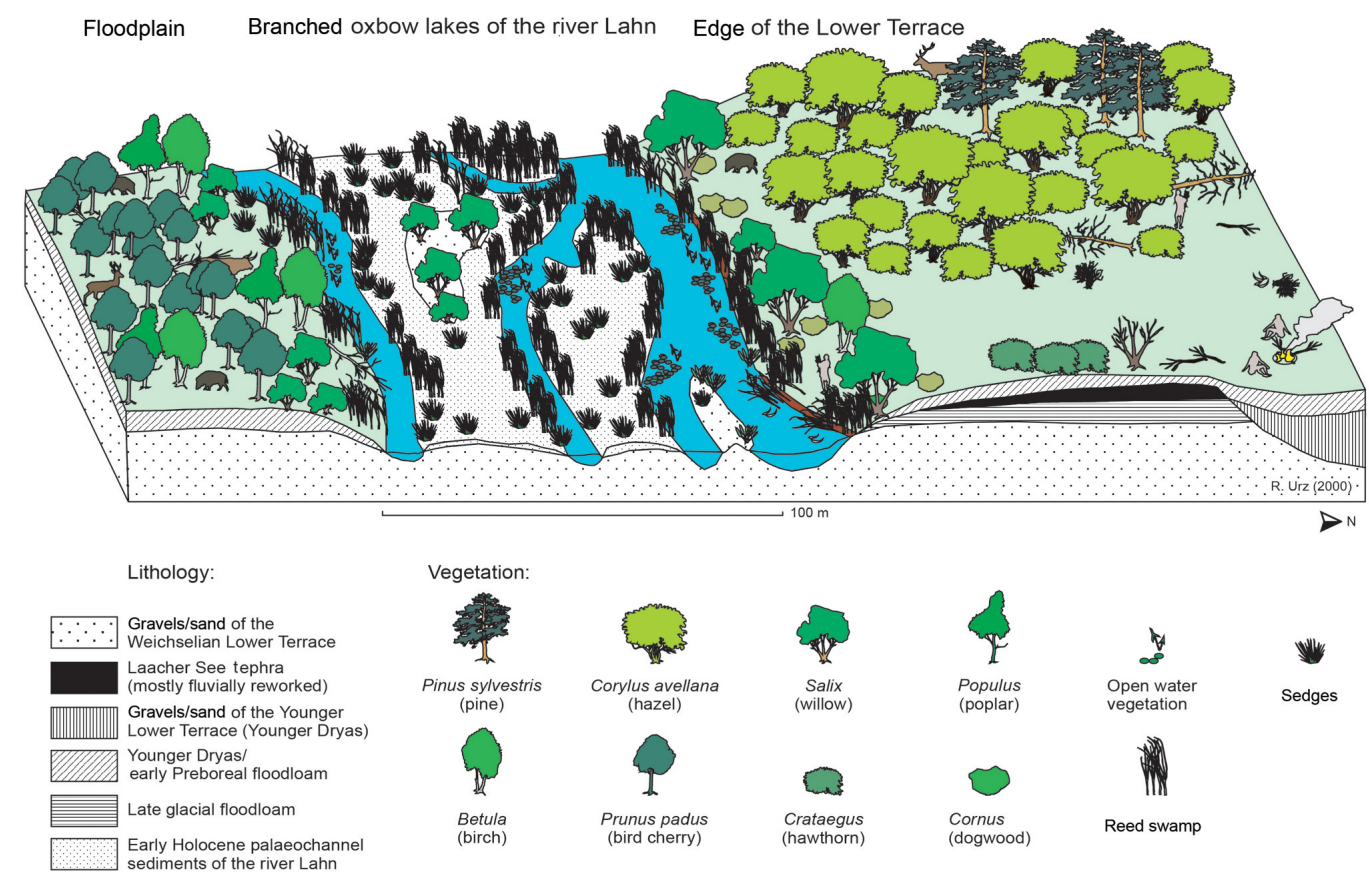

Figure 4. Palaeoenvironmental reconstruction of the fluvial landscape of the central Lahn river valley during the early Mesolithic occupation, showing the Mesolithic camp sites, the differences in relief between the floodplain and the terraces and accompanying differences in forest vegetation (Bos and Urz, 2003).

\subsubsection{Methods and results}

\section{Luminescence dating}

Different luminescence methods were applied in order to date the gravel units. Unfortunately, OSL dating of quartz has an upper age limit of around $100 \mathrm{ka}$ for the sediments in question (quartz dose rate 1.5 to $2.3 \mathrm{~Gy} \mathrm{ka}^{-1}$ ). The lower gravel units were thus too old for conventional OSL dating. For this reason, TT-OSL and post-IR IRSL 225 dating were tested as additional methods. However, both methods suffered from incomplete bleaching. Thus the ages need to be treated with care. Results are shown in Table 1 and Fig. 5.

\section{Heavy mineral analyses}

Sodium polytungstate with a density of $2.85 \mathrm{~g} \mathrm{~cm}^{-3}$ was used as heavy liquid to separate the heavy from the light fraction in a centrifuge. The samples were boiled with concentrated $\mathrm{HCl}$ before centrifugation in order to remove iron and manganese hydroxide crusts, which would complicate the identification. The disadvantage of this method is the dissolution of carbonate, apatite and parts of monazite and olivine (Boenigk, 1983). Nevertheless, this was deemed acceptable because of the benefit of being able to make comparisons with our own and other previous analyses.

The lowermost gravel units (Unit I and II) show a very low content of heavy minerals, with $0.02-0.09 \%$ in the fine sand fraction, while the other profile sections reveal heavy mineral contents ranging from 0.13 to $1.6 \%$. One of the key questions of this investigation was in which depth levels heavy minerals of volcanic origin, i.e. of the Laacher See tephra (LST) occur. The LST is characterized specifically by the volcanic heavy minerals pyroxene (augite), brown hornblende and titanite (e.g. Henningsen, 1980; Hilgers et al., 2003; Thiemeyer, 1993; Semmel, 2003), which comprise up to more than $75 \%$ of the overall heavy mineral fraction.

Samples from gravel Unit I and II show high amounts of extremely stable heavy minerals, especially zircon and tourmaline. The sample from the overlying gravel unit (Unit III), just below the floodplain fines, shows a significant increase of the heavy mineral content as well as high amounts of volcanic heavy minerals (pyroxene $75 \%$, brown hornblende $15 \%$ and titanite $3 \%$ ). It is thus assumed that at least parts of this gravel unit post-date the Laacher See event.

\subsubsection{Stratigraphic interpretation}

Due to the high sedimentation age of the lower gravel units, it is difficult to provide a numerical chronology of them. So far, only the following conclusions can be tentatively drawn.

The lowest gravel unit (Unit I) is probably older than the overlying unit. An assignment to a certain marine isotope stage (MIS) is impossible, but most likely the sample is older than $300 \mathrm{ka}$. 

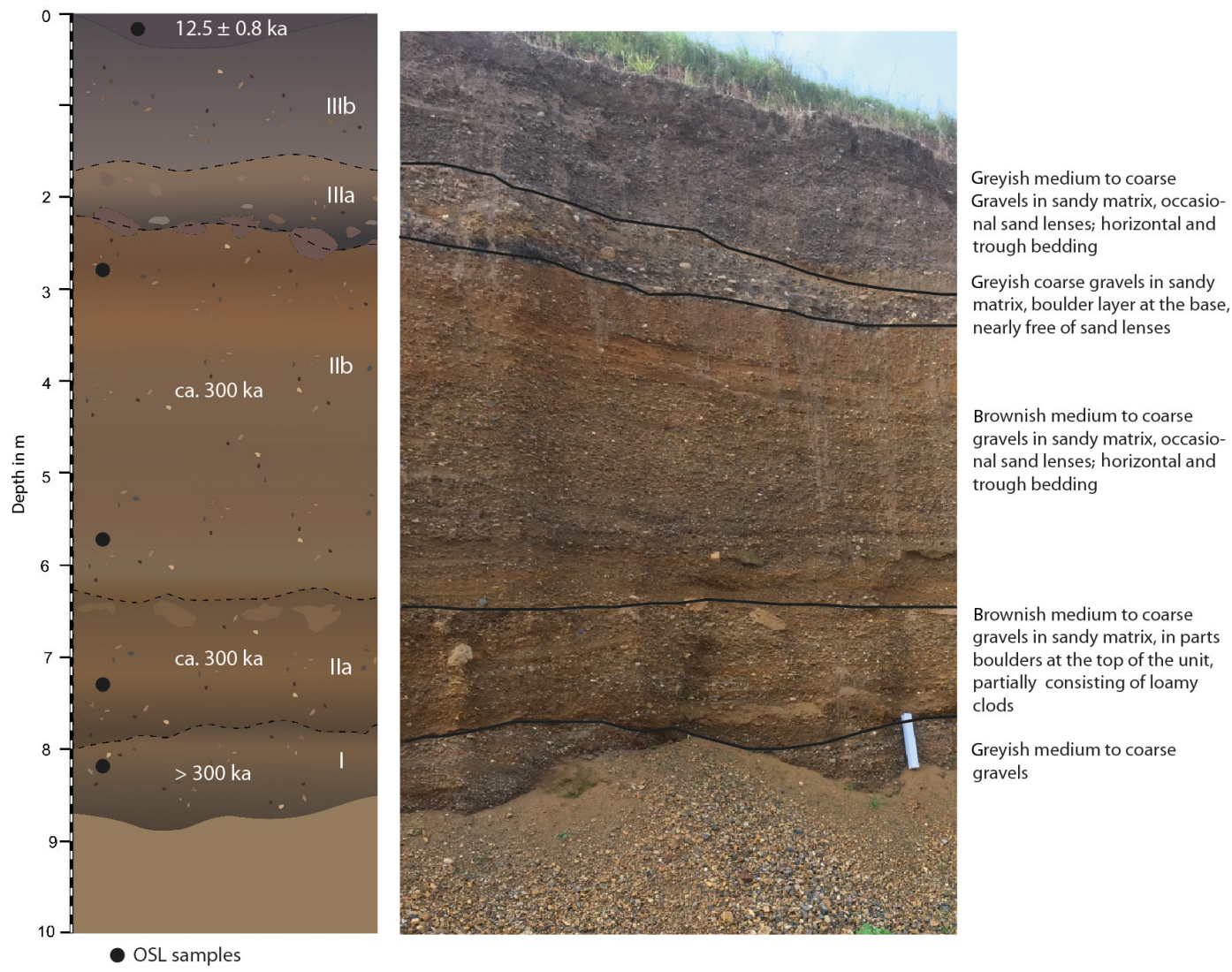

Figure 5. Sketch and photograph of the gravel units at the Niederweimar quarry. Also shown are age estimates based on (preliminary) luminescence ages (OSL, TT-OSL and pIRIR 225 dating). More detailed information on the ages is given in Table 1. Note that in the uppermost sample, heavy minerals typical of the Laacher See tephra were found.

Table 1. Luminescence ages (OSL, TT-OSL and pIRIR 225 ) of the gravel units in Niederweimar.

\begin{tabular}{lrrrrr}
\hline Sample & $\begin{array}{r}\text { Depth } \\
(\mathrm{m})\end{array}$ & Unit & $\begin{array}{r}\text { Quartz OSL age } \\
(\mathrm{ka})\end{array}$ & $\begin{array}{r}\text { Quartz TT-OSL age } \\
(\mathrm{ka})\end{array}$ & $\begin{array}{r}\text { Feldspar pIRIR age } \\
(\mathrm{ka})\end{array}$ \\
\hline GI464 & 4.2 & IIIb & $12.5 \pm 0.8$ & $42 \pm 3$ & $20 \pm 5$ \\
GI463 & 6.3 & IIb & & $307 \pm 21$ & $299 \pm 31$ \\
GI462 & 9.6 & IIb & & $291 \pm 29$ & $447 \pm 57$ \\
GI461 & 11.1 & IIa & & $323 \pm 28$ & $324 \pm 31$ \\
GI460 & 13.5 & I & & $408 \pm 70$ & $464 \pm 57$ \\
\hline
\end{tabular}

The intermediate gravel layer (Unit II) seems to have formed during one single glacial period, because the luminescence ages are of similar age (except for one outlier), independent of the method used. However, the ages are too imprecise and too unreliable for a clear assignment to a certain MIS. According to the luminescence ages, Unit II most likely formed during MIS 8 or MIS 10. This age strongly contradicts previous findings of Huckriede $(1972,1982)$ as well as Urz (1995) and Freund and Urz (2000), who place the base of the unit in the Eemian and early Weichselian, based on pollen and macrofossil analyses.
The uppermost gravel unit (Unit III) showed a surprisingly young age. So far, we have assigned this unit to the middle Weichselian because earlier, preliminary OSL ages clustered around $30 \mathrm{ka}$. Also, several ${ }^{14} \mathrm{C}$ ages between 30 and $40 \mathrm{ka}$ at Niederweimar and the nearby site of Niederwalgern (Urz, 1995; Freund and Urz, 2000) indicate an older age of this unit. It is possible that during the Younger Dryas, the gravels of the middle Weichselian were partially incised by the braided river that shaped the riverbed at that time. The channels were then filled with Younger Dryas gravels and sands shortly before the onset of the Holocene. In many parts of the upper gravel layer, these former channels are visible. This 


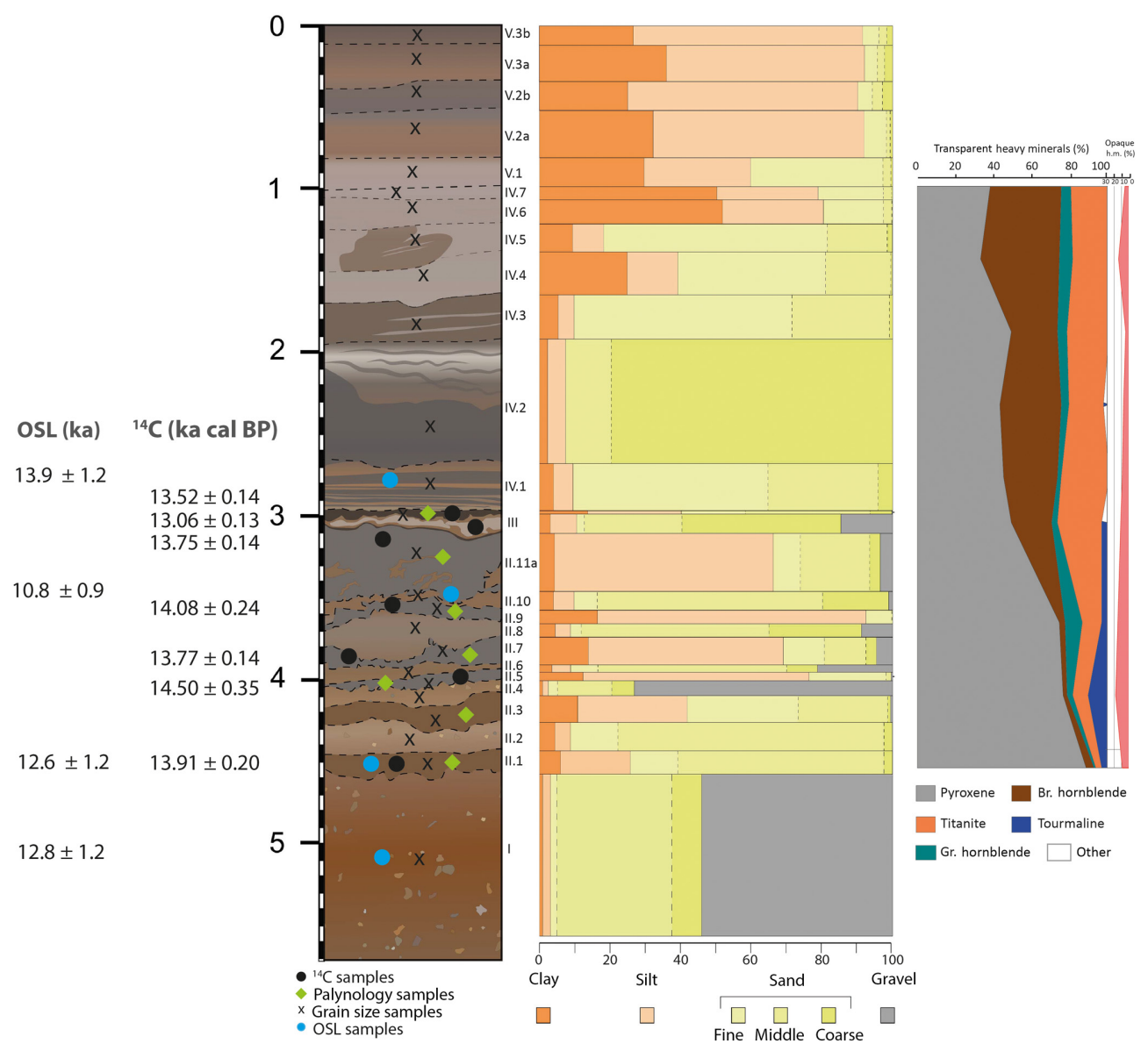

Figure 6. Sketch of section NW-6 in the floodplain loams of Niederweimar, together with results from ${ }^{14} \mathrm{C}$ and OSL dating, grain size and heavy mineral analyses. Please note that the lowermost sample for OSL dating is derived from one of the neighbouring sections NW-3, from the same stratigraphic unit.

young sedimentation age of the uppermost part of gravel Unit III is supported by the heavy mineral spectrum, which shows a signature characteristic of the LST.

Although the older luminescence ages have been unreliable so far, they allow the following overall interpretation: terrace units of different ages are vertically stacked onto each other, possibly indicating (relative) tectonic subsidence of the area. MIS 6 is not represented by a gravel unit in the studied section; thus it seems to have been completely removed by a later erosional period. Very large blocks in the lower part of Unit III testify to an extremely dynamic fluvial event, which may have caused this erosion. However, it cannot be ruled out that MIS 6 gravels are found in other parts of the gravel pit.

\subsection{Floodplain loams}

Floodplain loams overlie the Pleistocene gravels and show a very detailed stratigraphy, with alternating sand and silt layers in the lower part, one or several light grey layers of varying thickness in the middle and upper part, and a further dark palaeosol horizon in the uppermost part. From field observations, it is tempting to assign the greyish layers to the (relocated) Laacher See tephra, which would place the lower part of the floodplain loams in the late glacial and the upper part of the section mainly in the Holocene. This stratigraphy is supported by detailed pollen and macrofossil studies as well as radiocarbon dating carried out by, e.g. Urz (1995), Bos and Urz (2003) and Schirmer (1999). However, this stratigraphic interpretation contradicts the findings on the gravel unit investigated in the current study. Here, one OSL age places the uppermost part of the gravels in the Younger Dryas. Heavy mineral analyses also confirm that their deposition took place after the Laacher See event. In order to gain further insight into the chronostratigraphy of the site, further ${ }^{14} \mathrm{C}$ and OSL dating and palynological, granulometric and heavy mineral analyses on the floodplain loams were carried out.

\subsubsection{Methods and results}

Particle size distributions were determined by classical pipette and sieve procedures without decarbonation accord- 
Table 2. OSL and ${ }^{14} \mathrm{C}$ ages of the floodplain loams in Niederweimar. ${ }^{14} \mathrm{C}$ analyses were carried out on wooden macrofossils, and OSL dating was carried out on the quartz coarse grain fraction.

\begin{tabular}{lclcc}
\hline Sample & $\begin{array}{c}\text { Depth } \\
(\mathrm{m})\end{array}$ & Unit & $\begin{array}{c}\text { Quartz OSL age } \\
(\mathrm{ka})\end{array}$ & $\begin{array}{c}{ }^{14} \mathrm{C} \text { age } \\
(\mathrm{ka} \text { cal BP })\end{array}$ \\
\hline Poz-97127 & 3.00 & NW-6 III & & $13.52 \pm 0.14$ \\
Poz-97337 & 3.10 & NW-6 II.11b & & $13.06 \pm 0.13$ \\
Poz-97126 & 3.15 & NW-6 II.11a & & $13.75 \pm 0.14$ \\
Poz-97335 & 3.55 & NW-6 II.9 & & $14.08 \pm 0.24$ \\
Poz-97334 & 3.85 & NW-6 II.7 & & $13.77 \pm 0.14$ \\
Poz-97124 & 4.00 & NW-6 II.5 & & $14.50 \pm 0.35$ \\
Poz-97333 & 4.55 & NW-6 II.1a & & $13.91 \pm 0.20$ \\
GI455 & 2.75 & NW-6 IV.1 & $13.9 \pm 1.2$ & \\
GI453 & 3.50 & NW-6 II.10 & $10.8 \pm 0.9$ & \\
GI450 & 4.55 & NW-6 II.1 & $12.6 \pm 1.2$ & \\
GI448 & 5.00 & NW-3 I & $12.8 \pm 1.2$ & \\
\hline
\end{tabular}

ing to Köhn (ISO 11277). The chronology of the upper unit of floodplain fines is mainly based on calibrated ${ }^{14} \mathrm{C}$ age analyses (CalPal online; Weninger and Jöris, 2004), carried out on wooden macrofossils, obtained from the silt-rich sediment layers. Additionally, three luminescence ages were determined, using OSL on the coarse grain quartz fraction. Results are shown in Fig. 6 and Table 2.

Palynological analyses were carried out mainly on the silty layers in the bottom part of the section (Unit I to Unit III). They reveal vegetation changes over a short period of only 1000 years according to the ${ }^{14} \mathrm{C}$ ages (Fig. 7).

The layers II.1a and II.1c have similar pollen spectra with a dominance of Poaceae, Thalictrum, Artemisia and other herbs, such as the Helianthemum nummularium group, $R a-$ nunculus acris type, Apiaceae and Matricaria type, indicating a dominance of meadows. An open landscape is suggested by a low abundance of arboreal pollen (7\%), represented by Pinus and Betula. Presence of Myriophyllum and remains of Gleotrichia type and Spirogyra indicate stagnant or slowly flowing water. Pollen concentration is rather high and varies between 15000 and 27000 grains $\mathrm{cm}^{-3}$, indicating a low sedimentation rate. A low abundance of mycorrhizal spores of Glomus type indicates low soil erosion rates. Charcoal concentration of up to 6000 particles $\mathrm{cm}^{-3}$ reveals the presence of fires.

The next four clay layers (Units II.3, II.5, II.7, and II.9) differ from the first ones by very low pollen concentrations of 2000-3000 grains $\mathrm{cm}^{-3}$. This can possibly be explained by increased sedimentation rates due to enhanced soil erosion in the catchment. The latter is confirmed by a high abundance of Glomus type (87-302\%). Pollen spectra of all four layers are characterized by a significant increase of arboreal pollen like Picea (Bittmann, 2007), possibly partly reworked. Non-arboreal pollen (NAP) is still dominant in the spectrum with Cyperaceae, Poaceae and Artemisia, also suggesting wetter conditions and possible spread of tundra vegetation. Spores of coprophilous fungi (Arnium, Bombardioidea, Po- dospora, Sordaria and Sporormiella) indicate the presence of the herbivores in the area, but their increased abundance can possibly be explained by an increased soil erosion in the catchment. Pollen of Myriophyllum and algal remains indicates similar aquatic conditions to before. Interestingly, there are abundant sheaths of Gleotrichia-type, which is known as having been an aquatic pioneer during the early part of a late glacial due to its ability to fix nitrogen and make conditions suitable for other aquatic plants (van Geel et al., 1989).

Layer II.11 has an increased pollen concentration $\left(6000\right.$ grains $\left.\mathrm{cm}^{-3}\right)$, indicating a lower sedimentation rate during this period. The pollen concentration increases up to 64000 grains $\mathrm{cm}^{-3}$ in the peat layer, indicating a slow peat growth rate. An abundance of arboreal pollen (AP) in layer 11 exceeds $50 \%$ and it is dominated by Pinus and Betula, indicating further spread of birch-pine forests under milder conditions.

The heavy mineral samples from this section reveal a spectrum which is typical of the LST throughout the whole section of floodplain loams. Since especially pyroxene and brown hornblende are not very resistant to weathering, nearsurface samples are affected by a higher grade of mineral alteration, which causes a relative enrichment of the stable heavy mineral titanite.

\subsubsection{Stratigraphic interpretation}

The ${ }^{14} \mathrm{C}$ ages place the lower part of the floodplain loams in the Meiendorf and Bölling interstadials, as well as in the Older Dryas period. They coincide with ${ }^{14} \mathrm{C}$ ages presented by Schirmer (1999) for the same stratigraphic unit and predate the Laacher See eruption. Based on our investigations in the field, we placed the first layers containing LST in Unit III, supporting the ${ }^{14} \mathrm{C}$ ages. Furthermore, comparison of the preliminary pollen data with pollen diagrams presented in Schirmer (1999) allows a stratigraphical correlation of the lower part of our section to the late glacial. This is evidenced 


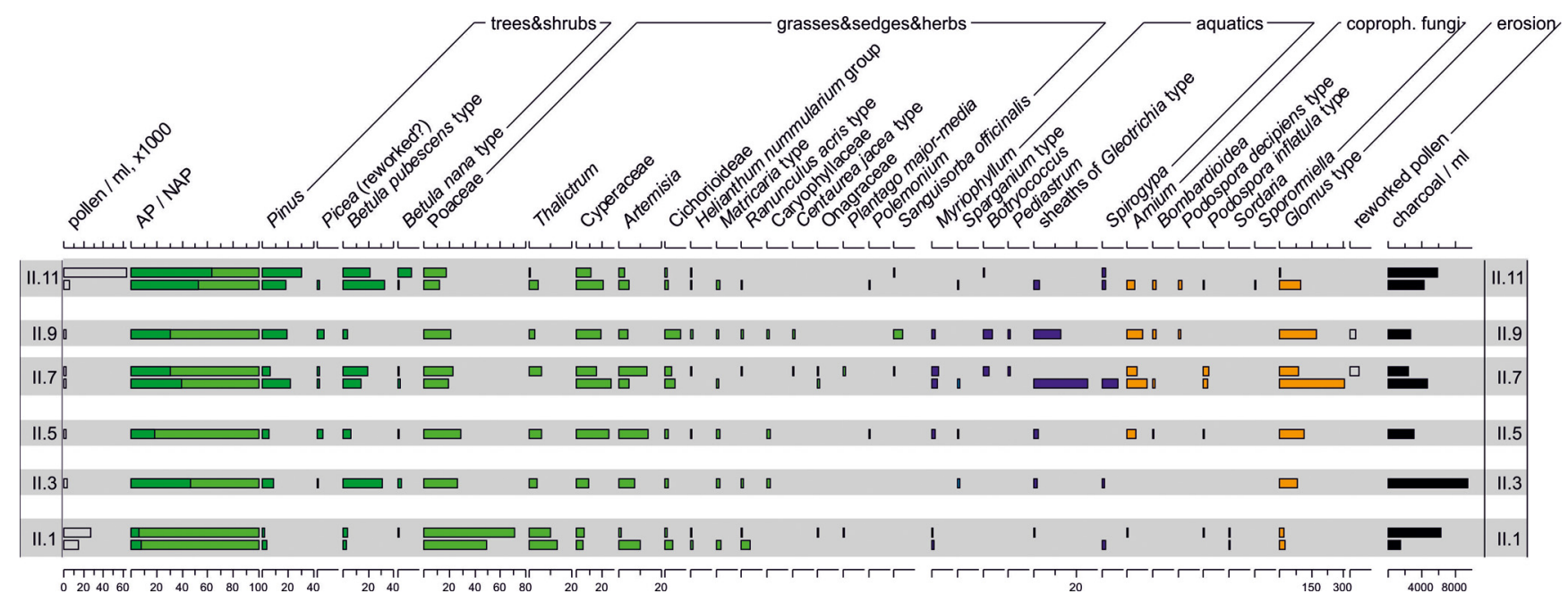

Figure 7. Selected curves from the palynological diagram of the section NW-6.

by rather low AP values, dominance of Betula, Poaceae and Artemisia and the presence of a wide variety of herbs such as Helianthemum, Plantago and Rumex acetosella type.

However, the heavy minerals suggest that layers from Unit II also contain significant amounts of LST, as well as the underlying gravel unit. This finding is consistent with two of the OSL dates from the floodplain loams, which yield ages of $12.6 \pm 1.2$ and $10.8 \pm 0.9 \mathrm{ka}$, thus post-dating the Laacher See event. Another OSL age from the underlying gravel $(12.8 \pm 1.2 \mathrm{ka})$ agrees with the Laacher See event and is consistent with another sample dated to $12.5 \pm 0.8 \mathrm{ka}$ investigated in the gravel section (see Sect. 3.3.1). However, the OSL chronology shows an age inversion in the uppermost sample. This is most likely due to methodological problems, namely OSL curves in this sample that decay slower than usual. The three lower samples showed typical OSL curves; they thus appear more reliable. On the other hand, the pollen data rule out a Holocene age of the middle OSL sample in the floodplain loams. The beginning of the Holocene in the area is well defined stratigraphically by a strong increase of pine pollen up to $80 \%$ (Bos and Urz, 2003), and this signature is absent in our investigated pollen samples.

In summary, on the one hand it seems that the OSL data and the heavy mineral analyses support each other, with the uppermost gravel unit and the overlying floodplain loams post-dating the Laacher See event. On the other hand, the ${ }^{14} \mathrm{C}$ chronology is more consistent with the pollen data and the field observations, i.e. the onset of tephra deposition within Unit III. This stratigraphic inconsistency will be further investigated in the near future.

The ${ }^{14} \mathrm{C}$ chronology furthermore reveals that the lower part of the section, comprising a sequence of intercalated coarser and finer layers (Unit II), was deposited within a relatively short time, resembling an alluvial channel facies ( $\mathrm{Au}$ rinnenfazies) sensu Schirmer (1983).

\section{Abandoned gravel quarry of Niederwalgern}

The site Niederwalgern is a former gravel quarry, which has now been turned into a lake that serves as a natural reserve for birds and other wildlife, and is also the habitat of a small herd of water buffalos. Geomorphologically, the former gravel quarry rests on the lower terrace of the Lahn, which in turn is covered by Holocene alluvial fines. The fines include a thick unit of sediments that contains abundant fragments of ceramics and charcoal, indicating anthropogenic alluvium which originates from hillslopes further to the west (Fig. 3). Detailed litho-, bio- and chronostratigraphic investigations at the site (during active quarrying) were carried out by Urz (1995).

\subsection{Methods and results}

Particle size distribution was determined by classical pipette and sieve procedures without decarbonation according to Köhn (ISO 11277). In order to provide a first chronology of the section, OSL dating was applied to the underlying gravels of the lower terrace and to the upper part of the overlying fine sediments. For this purpose, the coarse grain quartz fraction was analysed. Due to incomplete bleaching, the $D_{e}$ values of the floodplain fines are based on a minimum age model. In contrast, material from a sand lens within the underlying gravel was well bleached. Thus, the Central Age Model was applied for deriving the mean $D_{e}$. Results are summarized in Table 3 and Fig. 8.

\subsection{Stratigraphic interpretation}

The investigated section comprises three units: the gravel unit (I) at the base of this site yields an OSL age of $8.5 \pm 0.6 \mathrm{ka}$. In comparison to a ${ }^{14} \mathrm{C}$ age obtained by Urz (1995), which places this unit in the Younger Dryas, our 
Table 3. OSL ages of the quartz coarse grain fraction of the Niederwalgern section.

\begin{tabular}{rrrrr}
\hline Sample & $\begin{array}{r}\text { Depth } \\
(\mathrm{m})\end{array}$ & Unit & $\begin{array}{r}\text { Quartz OSL age } \\
(\mathrm{ka})\end{array}$ & $\begin{array}{r}\text { Quartz OSL age } \\
(\mathrm{AD})\end{array}$ \\
\hline GI465 & 0.55 & N-Wa III.5a & $1.00 \pm 0.07$ & $950-1090$ \\
GI466 & 0.75 & N-Wa III.4c & $0.89 \pm 0.09$ & $1040-1220$ \\
GI470 & 1.10 & N-Wa III.3b & $0.79 \pm 0.07$ & $1160-1290$ \\
GI467 & 1.40 & N-Wa III.3a & $1.16 \pm 0.10$ & $750-960$ \\
GI469 & 1.80 & N-Wa III.1 & $1.12 \pm 0.06$ & $830-970$ \\
GI468 & 3.75 & N-Wa I.3 & $8.5 \pm 0.6$ & \\
\hline
\end{tabular}
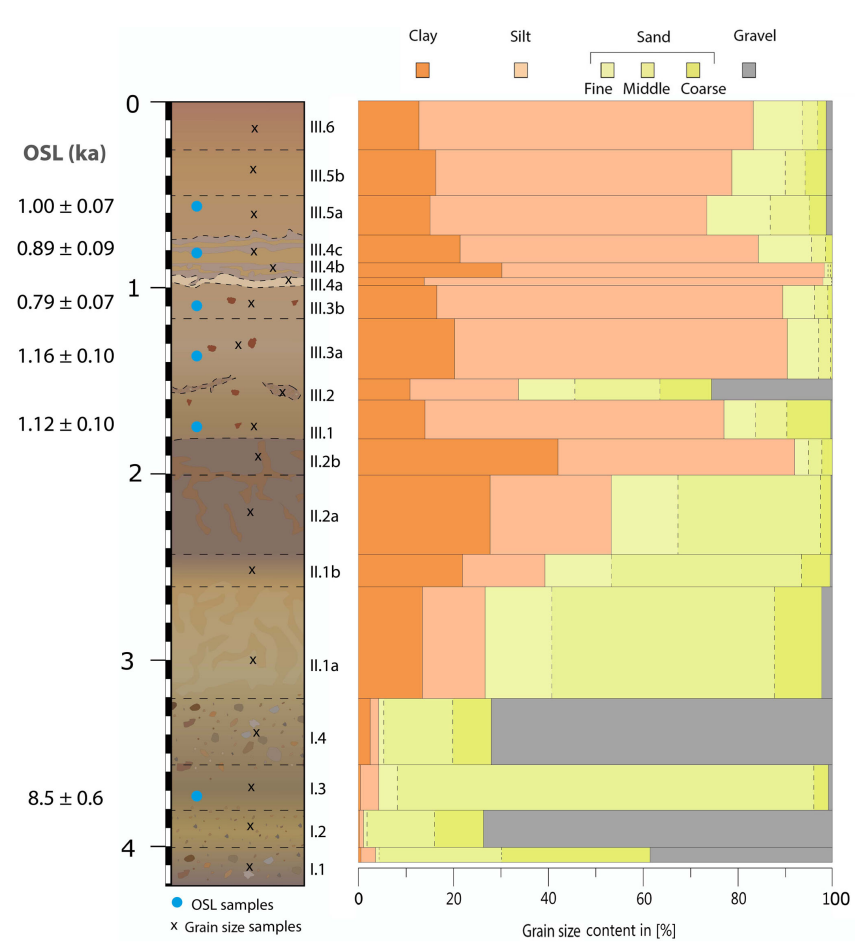

Figure 8. Sketch of section Niederwalgern, together with results of OSL dating (in ka) and grain size analyses.

OSL age appears to be too young. Further investigations on this issue will be undertaken in the near future.

The intermediate layer (II) is composed of floodplain loams with a dominant sand fraction. The unit terminates with a dark soil complex, in which the clay content increases to around $40 \%$ in the uppermost sample. This soil can possibly be correlated with the so-called black floodplain soil which is widespread in the area. The formation of this floodplain soil in middle Hesse is assigned to the early Holocene (Mäckel, 1969; Houben, 2002; Urz, 2003) or to the early to mid-Holocene (Rittweger et al., 2000). So far, precise numerical ages of this horizon have been sparse, and the site at Niederwalgern offers the potential for improving the chronology by undertaking further OSL analyses.

The sediments of the uppermost unit (III) are dominated by silt. Charcoal pieces and fragmented ceramics are also

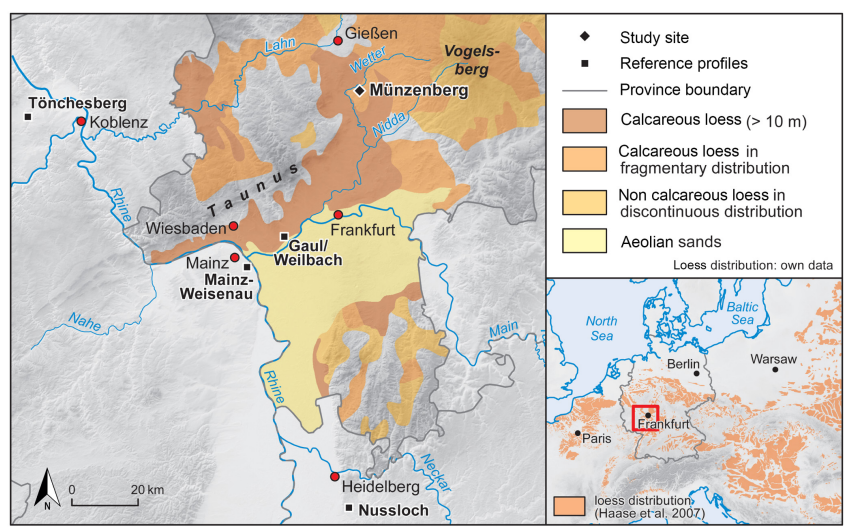

Figure 9. (a) Study area within the European loess belt (Haase et al., 2007). (b) Location of the Münzenberg loess sequence and reference sections. Loess distribution is only indicated for the region of Hesse (Germany). Please note that sedimentary units are strongly generalized.

abundant, indicating strong anthropogenic impact. At the current stage of research, it is however not clear whether this sediment layer is a colluvium from the small slopes further to the west or an alluvial sediment. Five OSL ages assign the unit to the Early Medieval Period in the lower part and the High Medieval Period in the upper part. As in many other parts of Germany, the High Medieval Period was characterized by deforestation and intensive farming, not only in the lowlands, but also on the hillslopes of low mountain ranges. This led to intense soil erosion and deposition of material at toe slopes and floodplains as colluvial and alluvial deposits.

\section{Münzenberg loess section}

\subsection{Study area}

The section is situated on a slope within a former brickyard on the east side of the Wetter River $\left(50^{\circ} 26^{\prime} \mathrm{N}, 08^{\circ} 46^{\prime} \mathrm{E}\right.$; $198 \mathrm{~m}$ a.s.l.), in the northern part of the Wetterau basin within the Hessian Depression (Fig. 9). The basin's topography is characterized by a gently rolling landscape, flanked by the northern Taunus mountains to the west and the basaltic Vogelsberg massif to the east. During the Tertiary, tectonic sub- 


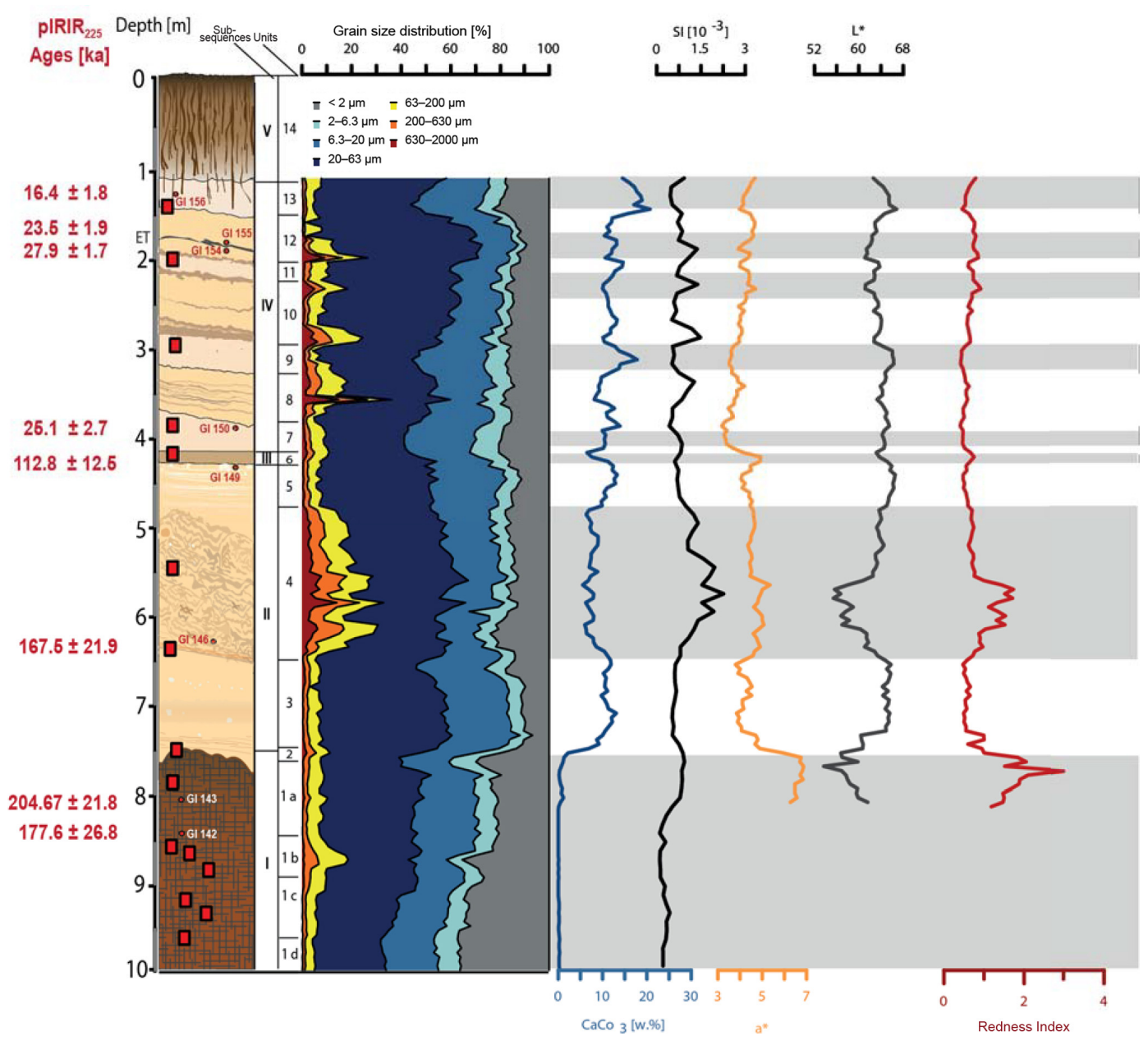

Figure 10. Results of sedimentological and colorimetric analyses at the Münzenberg section (5 cm depth interval except magnetic susceptibility with $10 \mathrm{~cm}$ depth interval): (a) grain size distribution, (b) carbonate content, (c) magnetic susceptibility measurements conducted in the field and (d) colour values a*, L* and Redness Index (RI), allowing estimations of hematite contents.

sidence created a mosaic of small-scale depressions, accompanied by the deposition of marine, fluvial, limnic and aeolian sediments (Bibus, 1974, 1976). Therefore, the lithology of the study area is dominated by unconsolidated Miocene sediments consisting of sands, gravels and clays. Additionally, Miocene basalts and intensively saprolized rock form the subsurface of the northern part of the Wetterau, characterizing the lithology of the study area (Kümmerle, 1981; Sabel, 1982).

Under periglacial conditions during the Pleistocene, the river Wetter formed terraces above the present-day river bed. These terraces were later covered by calcareous aeolian sands and reworked loess-derived clayey silts. On northeastfacing slopes and geomorphologically sheltered positions, loess was deposited and has been preserved to thicknesses of up to $10 \mathrm{~m}$ (Schönhals, 1996). Farming in the area already started in the early Neolithic, ca. 7500 years ago, favoured by a moderate climate and fertile soils. Because of this longterm cultivation, the present-day soilscape of the area is char- acterized by truncated soil profiles and anthropogenic colluvium, e.g. truncated Luvisols, Cambisols and Regosols (Houben, 2012; Lang and Nolte, 1999; Schrader, 1978).

\subsection{Methods}

According to Bibus (1974), the investigated loess section can be subdivided into 17 units, including several palaeosols showing different intensity of pedogenesis, reaching a thickness of up to $10 \mathrm{~m}$. However, the chronostratigraphic interpretation by Bibus (1976) was based solely on palaeopedological criteria, whereas there has been no numerical age control so far. Therefore, the existing loess profile has been extended, described and sampled in several field campaigns since summer 2013. Magnetic susceptibility measurements were conducted in the field with a SatisGeo Kappameter KM-7 at a $10 \mathrm{~cm}$ depth interval, recording five measurements per depth interval. Samples for sedimentological analyses were collected at high resolution $(5 \mathrm{~cm})$, yielding 180 bulk 
(a)

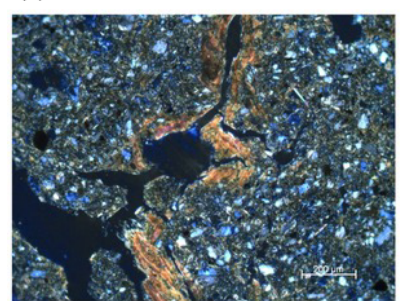

(c)

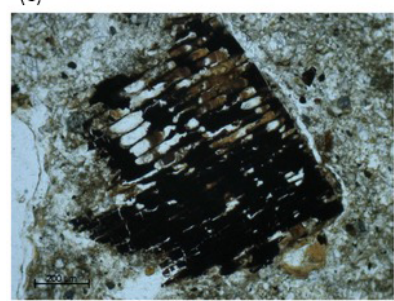

(b)

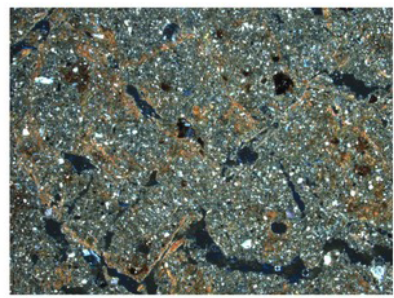

(d)

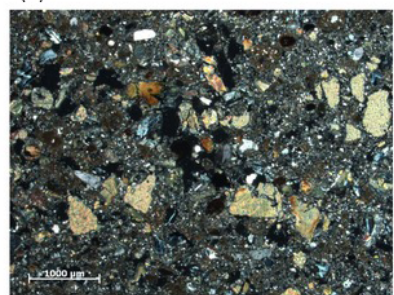

Figure 11. Photomicrographs of palaeosoil sediments. (a) The microstructure is characterized by numerous channels and planes, forming polygonal segments with coatings of illuvial clay. (b) Distribution of clay in striated b-fabric. (c) Charcoal. (d) Disorthic $\mathrm{Fe} / \mathrm{Mn}$ nodules.

samples, based on the continuous column sampling method described in Antoine et al. (2009). Sedimentological analyses included determination of particle size distribution by classical pipette and sieve procedures without decarbonation according to Köhn and gas-volumetric determination of carbonate using the Scheibler method. Additionally, spectrophotometric analysis for determination of colour and lightness was conducted using a Konica Minolta CM-5 spectrophotometer at the laboratory for Physical Geography of RWTH Aachen. Based on the colour values, the Redness Index (RI) was calculated as a proxy for soil rubification and changes in hematite content (Barron and Torrent, 1986). For luminescence dating, 16 samples (Fig. 10; red circles) were taken at night-time by direct sampling into opaque plastic bags, after removing the light-exposed outer sediment layer of the profile wall. Samples for dosimetry measurements were collected within a $30 \mathrm{~cm}$ radius of each luminescence sample. Sample preparation and post-IR IRSL measurements, following a modified post-IR IRSL 225 protocol originally proposed by Buylaert et al. (2009), were carried out at the Luminescence Laboratory of Giessen University. Further information can be found in Steup and Fuchs (2017). A total of 15 undisturbed samples were collected from the profile for micromorphological analyses (Fig. 10; red boxes).

For the interpretation of relative variations in the geochemical composition along the loess section, XRF analyses were performed on a ITRAX XRF core scanner at Bremen University. The results are presented as element log ratios (Fig. 12) to characterize weathering intensity and dust provenance.

\subsection{Profile description and results}

The division of the loess section into 14 pedostratigraphic units (Fig. 10) is based on field observations including identification of major discontinuities and variations in colour, grain size distribution, magnetic susceptibility and carbonate content, as well as quantitative analyses of grain size distribution, carbonate content, spectrophotometric colour measurements and age estimates obtained from luminescence dating. Five units are distinguished based on sedimentological and pedological characteristics from the basal stratum (I) of the sequence to the surface of the recent soil $(\mathrm{V})$ :
I. basal soil complex
II. calcareous loess and reworked soil sediment
III. weak brown soil sediment
IV. loess and tundra gleys
V. modern disturbed top soil.

The lowermost subsequence (Unit 1) of the section consists of $\mathrm{Fe} / \mathrm{Mn}$ nodules of reddish brown compacted clayey silt $\sim 2 \mathrm{~m}$ thick, characterized by complete decarbonatization. It shows the highest content of illuvial and neoformed clay $(<2 \mu \mathrm{m}$; Fig. $11 \mathrm{a}, \mathrm{b})$, with almost $40 \%$ clay at a depth of $10 \mathrm{~m}$. Four subunits can be distinguished within the basal soil complex, based on grain size variability and changes in soil colour and elemental composition (based on $\mathrm{XRF}$ ). The luminescence age estimates (Table 4) calculated from the pIRIR 225 signal in subunits $a$ and $b$ range from $177.6 \pm 26.8 \mathrm{ka}$ (GI 142) to $204.7 \pm 21.8 \mathrm{ka}$ (GI 143), indicating a time of deposition prior to the last interglacial (MIS $5 \mathrm{e})$ and therefore soil formation during MIS 5 or 7 .

Unit 2 marks a transitional stage between subsequence I and II, showing several indices for translocation, e.g. coarsening substrate, only partial decalcification and diffuse boundaries (Fig. 11c, d). It is superimposed by $1 \mathrm{~m}$ of homogeneous yellow-grey, calcareous $\left(11-12 \% \mathrm{CaCO}_{3}\right)$ and silty loess (Unit 3 ) with incorporated $\mathrm{CaCO}_{3}$ concretions $(\varnothing$ $5-6 \mathrm{~cm}$ ). Unit 4 differs clearly from the underlying and overlying typical calcareous loess layers (Units 3 and 5) in the occurrence of reworked yellowish brown to grey silt loams and sandy layers, both containing $\mathrm{Fe} / \mathrm{Mn}$ concretions and erosive and translocated structures. The uppermost laminated calcareous loess (Unit 5) of subsequence II is infiltrated with large calcareous nodules up to $15 \mathrm{~cm}$ in diameter and marks the boundary towards the overlying light brown reddish silt loam (Unit 6), with a tabular structure and a lower carbonate content compared to the loess sediments. Luminescence ages of the under- and overlying sediments confirm a gap of $\sim 100$ ka between subsequence II and IV, implying deposition of SS II during MIS 6 (GI 146: $167.5 \pm 21.9 \mathrm{ka}$ ). The overlying subsequence IV represents MIS 2 and is characterized by the alternation of yellow sandy loess sediments with 


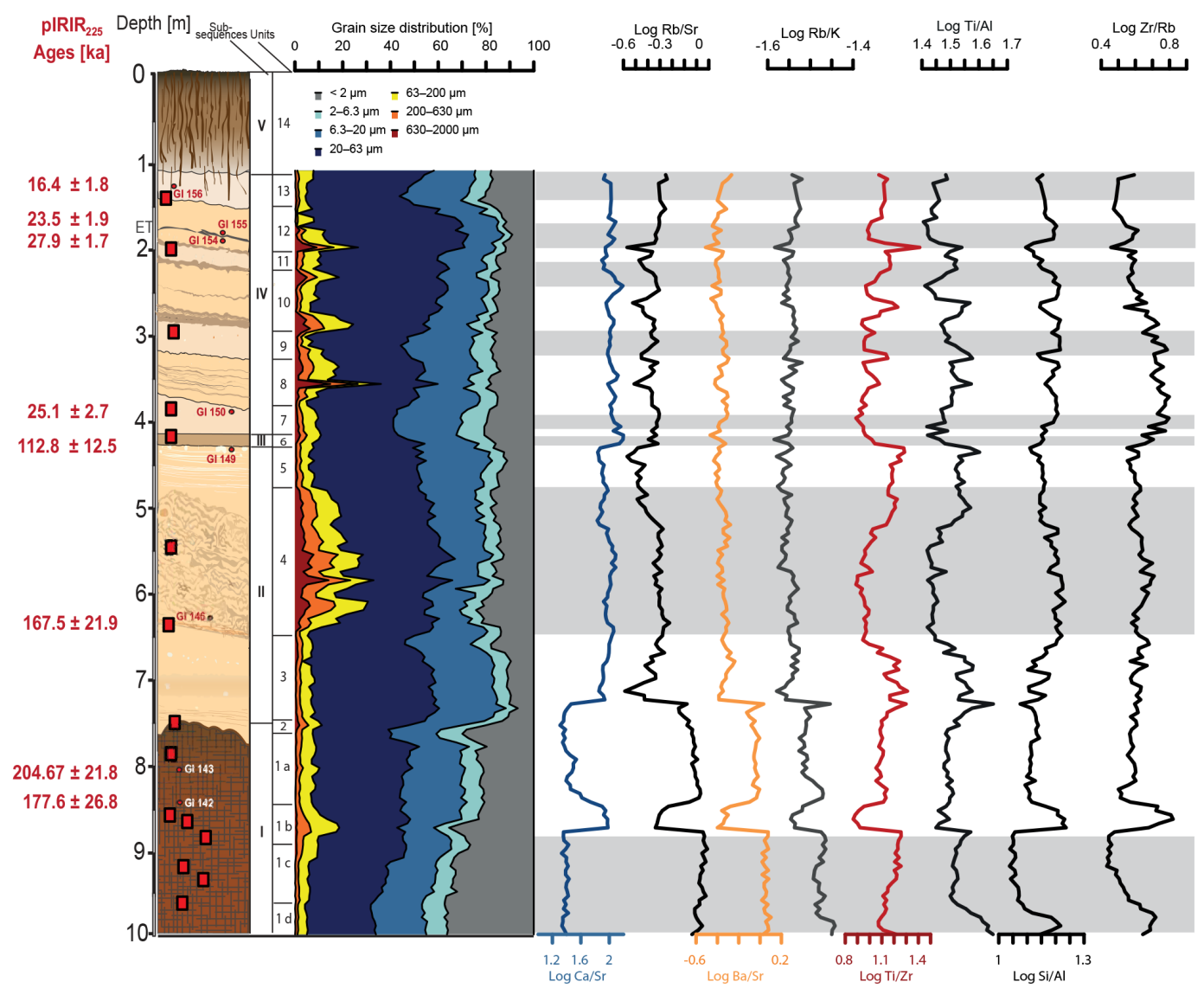

Figure 12. Grain size data, weathering and provenance indices at Münzenberg as derived from XRF data.

Table 4. Equivalent doses and post-IR IRSL dating results. The measurement column refers to the protocol used for age calculation; $n$ is the number of aliquots used for $D_{e}$ calculation. $D_{e}$ is the equivalent dose. The post-IR IRSL 225 ages are considered to be the most reliable age estimates.

\begin{tabular}{|c|c|c|c|c|c|}
\hline Sample & Depth $(\mathrm{cm})$ & Measurement & $n$ & $D_{e}(\mathrm{~Gy})$ & Uncorrected age (ka) \\
\hline GI 156 & $140-145$ & pIRIR $_{225}$ & 6 & $53.0 \pm 4.1$ & $16.4 \pm 1.8$ \\
\hline GI 155 & $175-182$ & pIRIR $_{225}$ & 4 & $70.2 \pm 4.0$ & $23.5 \pm 1.9$ \\
\hline GI 154 & $188-194$ & $\mathrm{pIRIR}_{225}$ & 7 & $82.6 \pm 2.5$ & $27.9 \pm 1.7$ \\
\hline GI 150 & $388-394$ & $\mathrm{pIRIR}_{225}$ & 7 & $75.5 \pm 5.3$ & $25.1 \pm 2.7$ \\
\hline GI 149 & $442-451$ & $\mathrm{pIRIR}_{225}$ & 8 & $350.8 \pm 26.3$ & $112.8 \pm 12.5$ \\
\hline GI 146 & $637-641$ & $\mathrm{pIRIR}_{225}$ & 8 & $399.5 \pm 46.7$ & $167.5 \pm 21.9$ \\
\hline \multirow[t]{6}{*}{ GI 143} & $802-805$ & $\mathrm{pIRIR}_{225}$ & 8 & $601.9 \pm 33.3$ & $204.7 \pm 21.8$ \\
\hline & & MET-IR $_{50}$ & 3 & $354.0 \pm 27.6$ & $120.4 \pm 14.4$ \\
\hline & & MET-pIRIR $_{100}$ & 3 & $530.0 \pm 29.0$ & $180.2 \pm 19.1$ \\
\hline & & MET-pIRIR $_{150}$ & 3 & $696.4 \pm 69.0$ & $236.8 \pm 31.9$ \\
\hline & & MET-pIRIR $_{200}$ & 3 & $640.0 \pm 61.6$ & $217.6 \pm 28.8$ \\
\hline & & MET-pIRIR $_{250}$ & 3 & $722.2 \pm 25.2$ & $245.6 \pm 23.9$ \\
\hline \multirow[t]{6}{*}{ GI 142} & 820 & $\mathrm{pIRIR}_{225}$ & 6 & $506.1 \pm 59.9$ & $177.6 \pm 26.8$ \\
\hline & & MET-IR $_{50}$ & 4 & $383.2 \pm 54.2$ & $134.5 \pm 22.8$ \\
\hline & & MET-pIRIR $_{100}$ & 4 & $471.5 \pm 82.6$ & $165.5 \pm 32.8$ \\
\hline & & MET-pIRIR $_{150}$ & 4 & $570.8 \pm 48.7$ & $200.3 \pm 25.3$ \\
\hline & & MET-pIRIR $_{200}$ & 4 & $719.6 \pm 122.2$ & $252.5 \pm 48.9$ \\
\hline & & MET-pIRIR $_{250}$ & 4 & $627.9 \pm 59.1$ & $220.3 \pm 29.2$ \\
\hline
\end{tabular}


intercalated coarser brownish sand layers (Units 8, 10, 12) and greyish yellow horizons with higher silt and lower sand contents, reflecting incipient pedogenesis (Units 7, 9, 11, 13). Transitions between sandy loess and bleached tongue horizons are represented by disturbed boundaries accompanied by redepositional features, such as rounded $\mathrm{Fe} / \mathrm{Mn}$ nodules and the highest coarse sand contents of the entire sequence. In the uppermost loess (Unit 12) a greyish-black layer of volcanic material $1-2 \mathrm{~mm}$ thin is observed, showing deformation features through solifluction processes. Based on the post-IR IRSL ages (GI 154 and GI 155), the volcanic ash layer can be attributed to the Eltville tephra, which serves as an important marker horizon and thus enables us to correlate the Münzenberg loess section with other sequences from central Germany containing this ash layer. The superimposed Unit 14 of subsequence $\mathrm{V}$ corresponds to the modern surface soil.

Data availability. Tables with primary data will be provided by the authors on request. See also www.hlnug.de/fileadmin/dokumente/ geologie/geologie/guek300.pdf (HLUG, 2017).

Author contributions. JL wrote the major part of the article, led the fieldwork and sampling and carried out luminescence dating for the research areas Niederweimar and Niederwalgern. RS wrote the part on Münzenberg, led fieldwork and sampling and carried out all analyses at Münzenberg. LS carried out the palynology and $\mathrm{CH}$ carried out the heavy mineral analyses. DS co-led fieldwork, carried out pedological investigations and organized radiocarbon dating. VvD carried out grain size analyses and prepared profile drawings. MF is the main organiser of the research team and research content.

Competing interests. The authors declare that they have no conflict of interest.

Acknowledgements. We would like to thank Andrea Junge, Tilmann Wolpert and Manual Pappusch for helping with fieldwork. We also greatly acknowledge the work of Julian Herche who provided some of the figures. Manfred Fischer is thanked for providing radionuclide data, and Stefanie Menges and Thomas Kolb are thanked for editing work on the manuscript.

\section{References}

Antoine, P., Rousseau, D.-D., Moine, O., Kunesh, S., Hatté, C., Lang, A., Tissoux, H., and Zöller, L.: Rapid and cyclic aeolian deposition during the Last Glacial in European loess: a highresolution record from Nussloch, Germany, Quaternary Sci. Rev., 28, 2955-2973, 2009.
Barron, V. and Torrent, J.: Use of the Kubelka - Munk theory to study the influence of iron oxides on soil colour, J. Soil Sci., 37, 499-510, 1986.

Bibus, E.: Abtragungs- und Bodenbildungsphasen im Rißlöß, E\&G Quaternary Sci. J., 25, 166-182, https://doi.org/10.3285/eg.25.1.14, 1974.

Bibus, E.: Zur geomorphologischen Fundsituation und Altersstellung der oberhessischen Geröllgeräte vom Münzenberger Typ, Rhein-Mainische Forschungen, 82, 179-203, 1976.

Bittmann, F.: Reconstruction of the Allerød vegetation of the Neuwied Basin, western Germany, and its surroundings at 12,900 cal B.P., Veg. Hist. Archaeobot., 16, 139-156, 2007.

Boenigk, W.: Schwermineralanalyse, 152 pp., Stuttgart (Enke), 1983.

Bos, J. A. A. and Urz, R.: Late Glacial and Early Holocene environment in the middle Lahn river valley (Hessen, central-west Germany) and the local impact of early Mesolithic people - pollen and macrofossil evidence, Veg. Hist. Archaeobot., 12, 19-36, 2003.

Buylaert, J. P., Murray, A. S., Thomsen, K. J., and Jain, M.: Testing the potential of an elevated temperature IRSL signal from K-feldspar, Radiat. Meas., 44, 560-565, 2009.

Freund, H. and Urz, R.: Ein frühweichselzeitliches Profil aus der Niederterrasse der mittleren Lahn (Weimar-Niederweimar, Hessen) - geologische, pollenanalytische und makrorestanalytische Untersuchungen, E\&G Quaternary Sci. J., 50, 107-123, https://doi.org/10.3285/eg.50.1.08, 2000.

Haase, D., Fink, J., Haase, G., Ruske, R., Pecsi, M., Richter, H., Altermann, M., and Jäger, K.-D.: Loess in Europe - its spatial distribution based on a European Loess Map, scale 1:2,500,000, Quaternary Sci. Rev., 26, 1301-1312, 2007.

Heine, K.: Fluß- und Talgeschichte im Raum Marburg. Eine geomorphologische Studie, Bonner Geographische Abhandlungen, 42, 195 pp., Bonn, 1970.

Henningsen, D.: Schwerminerale vulkanischer Herkunft in quartären Flußablagerungen der Weser und Leine, E\&G Quaternary Sci. J., 30, 63-72, https://doi.org/10.3285/eg.30.1.05, 1980.

Hilgers, A., Poetsch, A., and Semmel, A.: Jungpleistozäne und holozäne Böden und Bodenverlagerungen - ein Beispiel aus dem Taunusvorland bei Wiesbaden, Geologisches Jahrbuch Hessen, 130, 61-71, 2003.

HLUG: Geologische Übersichtskarte Hessen 1:300.000, 5. überarbeitete digitale Ausgabe, HLNUG, Wiesbaden, www.hlnug.de/ fileadmin/dokumente/geologie/geologie/guek300.pdf (last access: 18 July 2018), 2007.

Houben, P.: Die räumlich-zeitlich veränderte Reaktion des fluvialen Systems auf jungquartäre Klimaänderungen. Eine Fallstudie aus der Hessischen Senke, Diss. Univ. Frankfurt am Main, 189 pp., Frankfurt, 2002.

Houben, P.: Sediment budget for five millennia of tillage in the Rockenberg catchment (Wetterau loess basin, Germany), Quaternary Sci. Rev., 52, 12-23, 2012.

Huckriede, R.: Der Untergrund des Deutschen Hauses und weitere geologische und urgeschichtliche Befunde in Marburg an der Lahn, Geologica et Palaeontologica, 6, 177-201, 1972.

Huckriede, R.: Paläoklimatische Aussagen neuer weichselzeitlicher Pflanzenfunde in Hessen und Tirol, Physische Geographie, 5, 37-38, 1982. 
Kümmerle, E.: Erläuterungen zur Geologischen Karte von Hessen 1:25000, Blatt Nr. 5518 Butzbach, HLFB, 214 pp., Wiesbaden, 1981.

Lang, A. and Nolte, S.: The chronology of Holocene alluvial sediments from the Wetterau, Germany, provided by optical and 14 C dating, The Holocene, 9, 207-214, 1999.

Mäckel, R.: Untersuchungen zur jungquartären Flußgeschichte der Lahn in der Gießener Talweitung, E\&G Quaternary Sci. J., 20, 138-174, https://doi.org/10.3285/eg.20.1.14, 1969.

Rittweger, H.: The "Black Floodplain Soil" in the Amöneburger Becken, Germany: a lower Holocene marker horizon and indicator of an upper Atlantic to Subboreal dry period in Central Europe?, Catena, 41, 143-146, 2000.

Sabel, K. J.: Ursachen und Auswirkungen bodengeographischer Grenzen in der Wetterau (Hessen), Frankfurter geowissenschaftliche Arbeiten D, 3, 116 pp., 1982.

Schirmer, U.: Pollenstratigraphische Gliederung des Spätglazials im Rheinland, E\&G Quaternary Sci. J., 49, 132-143, https://doi.org/10.3285/eg.49.1.09, 1999.

Schirmer, W.: Die Talentwicklung an Main und Regnitz seit dem Hochwürm, Geologisches Jahrbuch, 71, 11-73, 1983.

Schönhals, E.: Ergebnisse bodenkundlicher Untersuchungen in der Hessischen Lößprovinz mit Beiträgen zur Genese des WürmLösses, Boden und Landschaft, 8, 251 pp., 1996.

Schrader, L.: Erläuterungen zur Bodenkarte von Hessen 1:25000, Blatt Nr. 5518 Butzbach, HLFB, 119 pp., Wiesbaden, 1978.

Semmel, A.: Der Laacher Bimstuff als Zeitmarke der Landschaftsentwicklung in der Wiesbadener Umgebung, Jahrbücher des Nassauischen Vereins für Naturkunde, 124, 95-109, 2003.
Steup, R. and Fuchs, M.: The loess sequence at Münzenberg (Wetterau/Germany): A reinterpretation based on new luminescence dating results, Zeitschrift für Geomorphologie, Supplementary Issues, 61, 101-120, 2017.

Thiemeyer, H.: Die Schwermineralführung des Würmlößprofils Mainz-Weisenau, Geologisches Jahrbuch Hessen, 121, 181-186, 1993.

Urz, R.: Jung-Quartär im Auenbereich der mittleren Lahn - Stratigraphische und paläontologische Untersuchungen zur Rekonstruktion vergangener Flusslandschaften, Dissertation, Universität Marburg/Lahn, 198 pp., 1995.

Urz, R.: Die jungpleistozäne Talfüllung der mittleren Lahn - ein Spiegel der kaltzeitlichen Klimaschwankungen im hessischen Mittelgebirge, Z. Geomorph. N.F., 47, 1-27, 2003.

van den Bogaard, P.: ${ }^{40} \mathrm{Ar} /{ }^{39} \mathrm{Ar}$ ages of sanidine phenocrysts from Laacher See Tephra (12,900 yr BP): Chronostratigraphic and petrological significance, Earth Planet. Sc. Lett., 133, 163-174, 1995.

van Geel, B., Coope, G. R., and van der Hammen, T.: Palaeoecology and stratigraphy of the Lateglacial type section at Usselo (The Netherlands), Rev. Palaeobot. Palyno., 60, 25-129, 1989.

Weninger, B. and Jöris, O.: Glacial Radiocarbon Age Calibration: the CalPal Program. Radiocarbon and Archaeology: 9-15, in: Radiocarbon and Archaeology, edited by: Higham, T., Bronk Ramsey, C., and Owen, C., Proceedings of the 4th Symposium, Oxford 2002, Oxford University School of Archaeology Monograph, 62, 9-15, 2004. 